\title{
Yield and uptake of bahiagrass under flooded environment as affected by nitrogen fertilization
}

\author{
Gilbert C. Sigua ${ }^{1^{*}}$, Mimi M. Williams ${ }^{2}$, Chad C. Chase $\mathrm{Jr}^{3}{ }^{3}$, Joseph Albano $^{4}$, Manoch Kongchum ${ }^{5}$ \\ ${ }^{1}$ United States Department of Agriculture-Agricultural Research Service, Florence, SC, USA \\ *Corresponding Author: gilbert.sigua@ars.usda.gov \\ ${ }^{2}$ United States Department of Agriculture-Natural Resources and Conservation Service, Brooksville, FL, USA \\ ${ }^{3}$ United States Department of Agriculture-Agricultural Research Service, Clay Center, NE, USA \\ ${ }^{4}$ United States Department of Agriculture-Agricultural Research Service, Fort Pierce, FL, USA \\ ${ }^{5}$ School of Plant, Environmental, and Soil Sciences, Louisiana State University Agricultural Center, Baton Rouge, LA, USA
}

Received 3 March 2012; revised 14 April 2012; accepted 9 May 2012

\section{ABSTRACT}

Bahiagrass (Paspalum notatum) is one of the most important forage grasses in subtropical region of USA and other tropical regions of the world. Although tolerant to short term flooding, bahiagrass is classified as a facultative upland (FACU+) species that suggest yield and plant persistence might be reduced under periods of extended waterlogging. The objective of this greenhouse study (2008-2009) was to determine the effect of nitrogen fertilization $(0,100$, and 200 $\mathrm{kg} \cdot \mathrm{N} \cdot \mathrm{ha}^{-1}$ ) on yield (DMY), crude protein content (CPC), and nitrogen uptake (NUP) of bahiagrass under varying flooded conditions $(0,14,28,56$, and 84 days). Results disclosed an overwhelming effect of $\mathrm{N}$ application on yield and uptake component of bahiagrass. Averaged across flooding duration, results showed that DMY $\left(R^{2}=\right.$ $\left.0.91^{* *}\right)$, CPC $\left(R^{2}=0.96^{* *}\right)$, and NUP $\left(R^{2}=0.99^{* *}\right)$ were linearly related to increasing levels of $N$ fertilization. Plants without $\mathbf{N}$ fertilization that were submerged between 14 to 84 days had significantly lower amount of DMY when compared with plants that were fertilized with 100 or 200 $\mathrm{kg} \cdot \mathrm{N} \cdot \mathrm{ha}^{-1}$. Comparable DMY and NUP were obtained between plants fertilized with $200 \mathrm{~kg} \cdot \mathrm{N} \cdot \mathrm{ha}^{-1}$ at 0 day of flooding $\left((11.7 \pm 5.0)\right.$ ton $\left.\cdot \mathrm{ha}^{-1}\right)$ and plants fertilized with $200 \mathrm{~kg} \cdot \mathrm{N} \cdot \mathrm{ha}^{-1}$ at 84 days of flooding $\left((9.8 \pm 2.7)\right.$ ton $\left.\cdot \mathrm{ha}^{-1}\right)$. The practical implication of this study is that waterlogging may hamper yield and uptake while nitrogen fertilization could improve yield and uptake of bahiagrass under waterlogged condition.

Keywords: Bahiagrass; Flooding; Nitrogen Uptake; Dry Matter Yield; Nitrogen

\section{INTRODUCTION}

Flooding can have catastrophic impacts on the productivity of bahiagrass, as most crops including many forage species that are intolerant to excess water. Particularly little is known about the response of bahiagrass to the combined effect of waterlogging and the addition of nutrients (e.g., $\mathrm{N}$ and $\mathrm{P}$ ). The use of $\mathrm{N}$ fertilizer prior to flooding may alleviate $\mathrm{N}$ deficiency because waterlogging causes a significant decrease in $\mathrm{N}$ content and rate of $\mathrm{N}$ accumulation in plants due to reduced root activity. Net assimilation rates and photosynthetic rates decline in plants experiencing root anaerobiosis, in part due to stomatal closure, and in part due to biochemical modifications [1,2]. Anaerobic conditions inhibit almost immediately the transport of nutrient ions by roots [3].

The cow-calf (Bos taurus) industry in subtropical United States especially in Gulf Coast states and other parts of the world depends almost totally on grazed pastures. Bahiagrass (Paspalum notatum) is one of the most important forage grasses grown in these regions of the world. Establishment of complete and uniform stand of bahiagrass in a short time period is important economically. Failure to obtain a good stand of bahiagrass means loss of not only the initial investment costs, but also production and its cash value [4]. In grasslands, waterlogging is frequently associated with other stresses, such as grazing, which may require specific and very different adaptive strategies and management [5,6]. Different plant species, including bahiagrass vary in their ability to withstand flooding and this undoubtedly contributes to their ecological distribution [7]. These adaptive strategies are not well understood and may still warrant extended investigations.

Relatively few studies and reports are available on the ability of $\mathrm{N}$ fertilizer to counteract the deleterious effects of waterlogging on terrestrial plants $[8,9]$. If additional fertilizer applications can improve the tolerance of forage 
grasses to waterlogging, then market value of environmental service of water storage will need to be adjusted to include additional fertilizer costs. Our hypothesis in this study is that bahiagrass will be negatively affected by extended flooding and $\mathrm{N}$ application could offset the potential negative effect of flooding on its yield, crude protein content, and nutrient uptake. The objective of this greenhouse study (2008-2009) was to determine the effect of nitrogen fertilization $\left(0,100\right.$, and $\left.200 \mathrm{~kg} \cdot \mathrm{N} \cdot \mathrm{ha}^{-1}\right)$ on yield, crude protein content, and nitrogen uptake of bahiagrass under varying flooded conditions $(0,14,28$, 56, and 84 days).

\section{MATERIALS AND METHODS}

\subsection{Preparation of Soils Media and Plant Materials}

Soils needed for this two-year study (2008-2009) were obtained using a back-hoe from a Blichton soil series (loamy, siliceous, hyperthermic, Arenic Paleaudults) at a depth of $0-20 \mathrm{~cm}$ from a pasture at the USDA-ARS Subtropical Agriculture Research Station (STARS), Brooksville, FL in 2008 and 2009. The soil was air dried outside on an impervious surface at USDA-NRCS Plant Material Center (PMC), Brooksville, FL. Prior to drying, eight to 10 random samples were collected to determine some selected soil physical and initial soil chemical properties (Table 1). Blichton soils are poorly drained soils with water table at a depth of less than $25 \mathrm{~cm}$ for cumulative periods of 1 to 4 months during most years. These soils, like many of the soils in south Florida, have argillic and spodic horizons.

The introduced species of bahiagrass (cv. Tifton-9) was used in the study. All the plant materials were excavated from established stands of bahiagrass at STARS pasture. Approximately $15 \times 10 \mathrm{~cm}$ plugs consisting of crowns, rhizomes, and roots (trimmed off to approx. $10-\mathrm{cm}$ stubble height) were transplanted from the field 12 weeks prior to the initiation of the study each year. The plugs were planted into $15 \times 60 \mathrm{~cm}$ planting columns that have been filled to within approximately 15 $\mathrm{cm}$ of the surface with the air dried, screened $(1 \times 1 \mathrm{~cm}$ screen) soils from the A horizon of Blichton series. The planting columns were sealed at the bottom to control water movement through the column. A hole was drilled at the side of the column and fitted with a drain tube with a stopcock to allow draining and sampling of the soil solution.

\subsection{Experimental Treatments (Greenhouse Condition)}

Immediately after planting, the columns with open drain tubes were moved into the greenhouse $\left(22^{\circ} / 32^{\circ} \mathrm{C}\right.$,
Table 1. Selected physical and chemical properties of soils used in the study.

\begin{tabular}{ccc}
\hline Soil Properties & Unit & Value \\
\hline Particle Size & $\mathrm{g} \cdot \mathrm{kg}^{-1}$ & 868 \\
Sand & $\mathrm{g} \cdot \mathrm{kg}^{-1}$ & 75 \\
Silt & $\mathrm{g} \cdot \mathrm{kg}^{-1}$ & 57 \\
Clay & $\mathrm{cm} \cdot \mathrm{hr}^{-1}$ & 7.0 \\
Hydraulic Conductivity & $\mathrm{kg} \cdot \mathrm{m}^{-3}$ & 1.4 \\
Bulk Density & $\mathrm{meq} \cdot 100 \cdot \mathrm{g}^{-1}$ & 11.2 \\
Cation Exchange Capacity (CEC) & $\mathrm{mg} \cdot \mathrm{kg}^{-1}$ & 2.9 \\
Ca & $\mathrm{mg} \cdot \mathrm{kg}^{-1}$ & 0.5 \\
$\mathrm{Mg}$ & $\mathrm{mg} \cdot \mathrm{kg}^{-1}$ & 0.1 \\
$\mathrm{Na}$ & $\mathrm{mg} \cdot \mathrm{kg}^{-1}$ & 0.1 \\
$\mathrm{~K}$ & & 5.5 \\
$\mathrm{pH}$ &
\end{tabular}

$69 \%$ direct light) at the USDA-NRCS Plant Material Center greenhouse and allowed to recover and grow during the $12 \mathrm{wk}$ pre-trial period. During the first four weeks of the pre-trial period, the plants were fertilized with a soluble complete fertilizer equivalent to $23 \mathrm{~kg}$ total of $\mathrm{N}, \mathrm{P}$, and $\mathrm{K}$, and then fertilization discontinued. During the remainder of the adjustment periods (12 weeks), the plants were watered as needed to maintain the approximate soil field capacity.

Treatments were replicated five times using a $5 \times 3$ split plot arrangement in completely randomized block design. Flooding duration was the main treatment effect while $\mathrm{N}$ fertilization was the sub-plot feature. All columns received $40 \mathrm{~kg} \cdot \mathrm{ha}^{-1}$ of $\mathrm{p}$ as triple super phosphate granular fertilizer and appropriate $\mathrm{N}$ fertility treatments consisted of 0,100 , and $200 \mathrm{~kg} \cdot \mathrm{ha}^{-1}$ of $\mathrm{N}$ as $\mathrm{NH}_{4} \mathrm{NO}_{3}$ were applied to the appropriate columns. The soil flooding duration was consisted of 0-, 14-, 28-, 56-, and 84days to mimic flooding occurrences in south Florida that may be associated with the need to temporarily store rainfall on pastureland in the summer. Flooding treatments were staggered such that termination of all flooding duration times coincided with the maximum flooding time of 84 days. For plants not receiving flood treatment, soil moisture was maintained at soil field capacity limit. Until a flooding treatment was started, all drain tubes remained open and the treatments were watered.

\subsection{Plant Yield and Tissue Analysis}

All treatments were destructively sampled at the end of maximum flooding time treatment of 84 days. Freshly cut aboveground growth was oven-dried at $60^{\circ} \mathrm{C}$ for 24 hours at the USDA-ARS Laboratory in Brooksville, FL. Plant samples were ground to pass through a 1-mm mesh screen in a Wiley mill. Ground forage was analyzed for 
total Kjeldahl nitrogen concentration [10] at the University of Florida Analytical Research Laboratory, Gainesville, FL. Crude protein content (\%) and total nitrogen uptake $\left(\mathrm{kg} \cdot \mathrm{N} \cdot \mathrm{ha}^{-1}\right)$ were calculated using the equations below:

$$
\begin{aligned}
& \text { Crude Protein Content } \\
& =\text { Nitrogen Concentration } \times 6.25 \\
& \text { Total Nitrogen Uptake } \\
& =\text { DMY } \times \text { Nitrogen Concentration }
\end{aligned}
$$

\subsection{Redox Potential Measurements}

Reduction-oxidation (Redox) potential of the soil solution was determined in 2008 (June 22 to September 4) and 2009 (June 23 to September 5) to monitor soil oxygen condition. Soil redox potential measurements have been used to characterize the intensity of reduction and oxidation and relate this to biological processes occurring in flooded soils. Measurements consist of three pieces of equipment: platinum electrode, reference electrode, and voltmeter. The platinum electrode and the reference electrode (calomel) were both buried into the soil column (7 - $10 \mathrm{~cm}$ depths) to be in contact with the soil solution. Wires from both the platinum electrode and reference electrode were connected to a voltmeter. The redox potential was reported based on standard hydrogen electrode (SHE) by adding value of +245 to the reading from the meter.

\subsection{Statistical Analysis}

The effects of flooding and $\mathrm{N}$ application on DMY, CPC, and NUP of bahiagrass were analyzed statistically following the PROC GLM procedures [11]. Where the F-test indicated a significant $(p \leq 0.05)$ effect, means were separated, following the method of LSD test and Duncan Multiple Range test, using appropriate mean squares [11].

\section{RESULTS AND DISCUSSION}

\subsection{Effects on Dry Matter Yield}

Dry matter yield of bahiagrass varied significantly ( $\mathrm{p} \leq$ 0.0001 ) with $\mathrm{N}$ fertilization, but was neither affected by flooding duration nor by the interaction of flooding duration and $\mathrm{N}$ fertilization (Table 2). The greatest DMY for bahiagrass of $12.3 \mathrm{ton} \cdot \mathrm{ha}^{-1}$ was from tube with 14 days of flooding that was fertilized with $200 \mathrm{~kg} \cdot \mathrm{N} \cdot \mathrm{ha}^{-1}$ while the least amount of DMY (2.7 ton $\cdot \mathrm{ha}^{-1}$ ) was from tube that was flooded for 84 days and fertilized with 0 $\mathrm{kg} \cdot \mathrm{N} \cdot \mathrm{ha}^{-1}$. Results disclosed an overwhelming effect of $\mathrm{N}$ application on DMY. This claim was exhibited by a much higher DMY under any flooding duration of plants that received higher $\mathrm{N}$ application as opposed to those plants without $\mathrm{N}$ fertilization.

Quite crucial to the interpretation of our results is the limited amount of oxygen that may be present following

\begin{tabular}{|c|c|c|c|c|}
\hline $\begin{array}{c}\begin{array}{c}\text { Flooding Duration } \\
\text { (days) }\end{array} \\
\end{array}$ & $\begin{array}{c}\text { Nitrogen Level } \\
\left(\mathrm{kg} \cdot \mathrm{N} \cdot \mathrm{ha}^{-1}\right)\end{array}$ & Dry Matter Yield (ton $\cdot h^{-1}$ ) & Crude Protein Content (\%) & $\begin{array}{c}\text { Total Nitrogen Uptake } \\
\left(\mathrm{kg} \cdot \mathrm{ha}^{-1}\right)\end{array}$ \\
\hline \multirow{3}{*}{0} & 0 & $5.6 \pm 2.4$ & $5.6 \pm 0.4$ & $50.0 \pm 21.7$ \\
\hline & 100 & $9.8 \pm 2.4$ & $5.5 \pm 0.9$ & $84.5 \pm 18.9$ \\
\hline & 200 & $11.7 \pm 5.0$ & $10.1 \pm 2.4$ & $187.6 \pm 85.2$ \\
\hline \multirow{3}{*}{14} & 0 & $5.9 \pm 2.9$ & $4.8 \pm 1.0$ & $46.6 \pm 24.1$ \\
\hline & 100 & $11.8 \pm 2.7$ & $6.1 \pm 1.7$ & $112.8 \pm 27.9$ \\
\hline & 200 & $12.3 \pm 2.8$ & $9.5 \pm 1.6$ & $181.6 \pm 14.8$ \\
\hline \multirow{3}{*}{28} & 0 & $6.2 \pm 2.4$ & $5.1 \pm 0.6$ & $51.9 \pm 24.8$ \\
\hline & 100 & $7.1 \pm 2.6$ & $9.7 \pm 2.5$ & $110.6 \pm 49.6$ \\
\hline & 200 & $11.3 \pm 3.2$ & $9.2 \pm 1.7$ & $160.6 \pm 23.9$ \\
\hline \multirow{3}{*}{56} & 0 & $6.2 \pm 2.4$ & $5.7 \pm 1.6$ & $59.5 \pm 35.0$ \\
\hline & 100 & $11.9 \pm 3.2$ & $5.7 \pm 2.6$ & $82.7 \pm 40.3$ \\
\hline & 200 & $9.5 \pm 4.9$ & $8.9 \pm 1.3$ & $128.6 \pm 52.9$ \\
\hline \multirow{3}{*}{84} & 0 & $2.7 \pm 0.8$ & $4.5 \pm 0.8$ & $23.0 \pm 4.6$ \\
\hline & 100 & $7.8 \pm 1.1$ & $6.4 \pm 1.7$ & $79.5 \pm 21.1$ \\
\hline & 200 & $9.8 \pm 2.7$ & $6.8 \pm 1.1$ & $105.7 \pm 27.2$ \\
\hline Sources of Variation & & & F-values & \\
\hline Flooding (F) & & $2.04^{\mathrm{ns}}$ & $2.2^{\mathrm{ns}}$ & $2.36^{\mathrm{ns}}$ \\
\hline Nitrogen $(\mathrm{N})$ & & $19.46^{* * *}$ & $25.3^{* * *}$ & $33.80^{* * *}$ \\
\hline $\mathrm{F} \times \mathrm{N}$ & & $0.90^{\mathrm{ns}}$ & $3.03^{* *}$ & $0.96^{\mathrm{ns}}$ \\
\hline
\end{tabular}
flooding. Oxygen level was indirectly measured using

Table 2. Yield, crude protein content, and nitrogen uptake of bahiagrass as affected by different flooding duration at different levels of nitrogen fertilization.

ns —not significant; ${ }^{* *}$ —significant at $\mathrm{p} \leq 0.001 ;{ }^{* * *}$ — significant at $\mathrm{p} \leq 0.0001$. 
the reduction-oxidation potentials (redox). Redox potential is an electrical measurement that shows the tendency of a soil solution to transfer electrons to or from a reference electrode. This measurement can estimate whether the soil is fully or partly aerobic or in anaerobic condition. Figure 1 shows the different levels of redox potential readings from soils that were flooded from 0 to 84 days. Redox potentials (Eh values, $\mathrm{mV}$ ) of the soils that were flooded from 0 to 84 days ranged from $400 \mathrm{mV}$ to $-150 \mathrm{mV}$. Except for the non-flooded (control) soils, all the soils attained the stage of anaerobic conditions between 8 - 10 days and became fully anaerobic thereafter. An Eh reading below $0 \mathrm{mV}$ would mean limited supply of oxygen in the soil (Figure 1). It is generally accepted that energy deficit is one of the most severe problems encountered by plants when subjected to flooding. Oxygen is the terminal acceptor of electrons in the oxidative phosphorylation that indirectly provides the plant with ATP [12].

The effect of $\mathrm{N}$ fertilization on DMY is shown in Figure 2(a). The amount of DMY increased linearly with increasing amount of $\mathrm{N}$ fertilization when averaged across flooding duration. The relationship between DMY and levels of $\mathrm{N}$ fertilization was described by the regression model given below:

$$
\begin{aligned}
& \mathrm{DMY}_{\text {Bahiagrass }}=2.81 \mathrm{x}+3.04 \\
& R^{2}=0.91^{* *}
\end{aligned}
$$

Our results show that bahiagrass having the ability to tolerate waterlogging is a tool not only to survive in such environment, but also to respond to growth stimulating factor, such as $\mathrm{N}$ fertilization. We can assume that soil $\mathrm{N}$ availability was quite similar in both waterlogged and non-waterlogged treatments. Nitrogen fertilization indi- cated a positive result on DMY of bahiagrass [13,14]. Results are suggesting that waterlogging does not produce detrimental effect either in the growth of bahiagrass or its response capacity to stimulating growth factors, such as $\mathrm{N}$ fertilization.

As shown in Figure 3(a), the DMY of bahiagrass was relatively comparable across flooding duration. This forage can be identified as somewhat tolerant to waterlogging. While extended period of flooding did not affect total biomass of bahiagrass, waterlogging slightly promoted their growth. For plants to be classified as tolerant to waterlogging can still maintain their growth rate in such condition [15-18]. Although flooding typically causes a reduction in the abundance of flood-sensitive plant species, it can also promote biomass growth in flood-tolerant species to exploit resources that otherwise would be shared with non-tolerant competitors $[19,20]$. Voesenek et al. [12] suggested that hormonal effects were involved in growth response for plants under waterlogged conditions because photosynthesis rates could be enhanced by increased leaf temperature at higher air vapor pressure deficit in most $\mathrm{C}_{4}$ grasses (e.g., bahiagrass) while differrences in photosynthetic activities between flooded and control plants may be accounted for by the differences in stomatal conductance.

Our visual observations during the experiment suggest that the aboveground biomass of bahiagrass under waterlogged conditions were similar with non-waterlogged forage species. Recent studies in grasslands of Argentina found that native grasses present plastic responses to flooding, such as aerenchyma tissue formation and increase in plant height $[6,18]$. Aerenchyma formation and leaf elongation are important for the recovery of contact with aerial environment and allow oxygen transport to

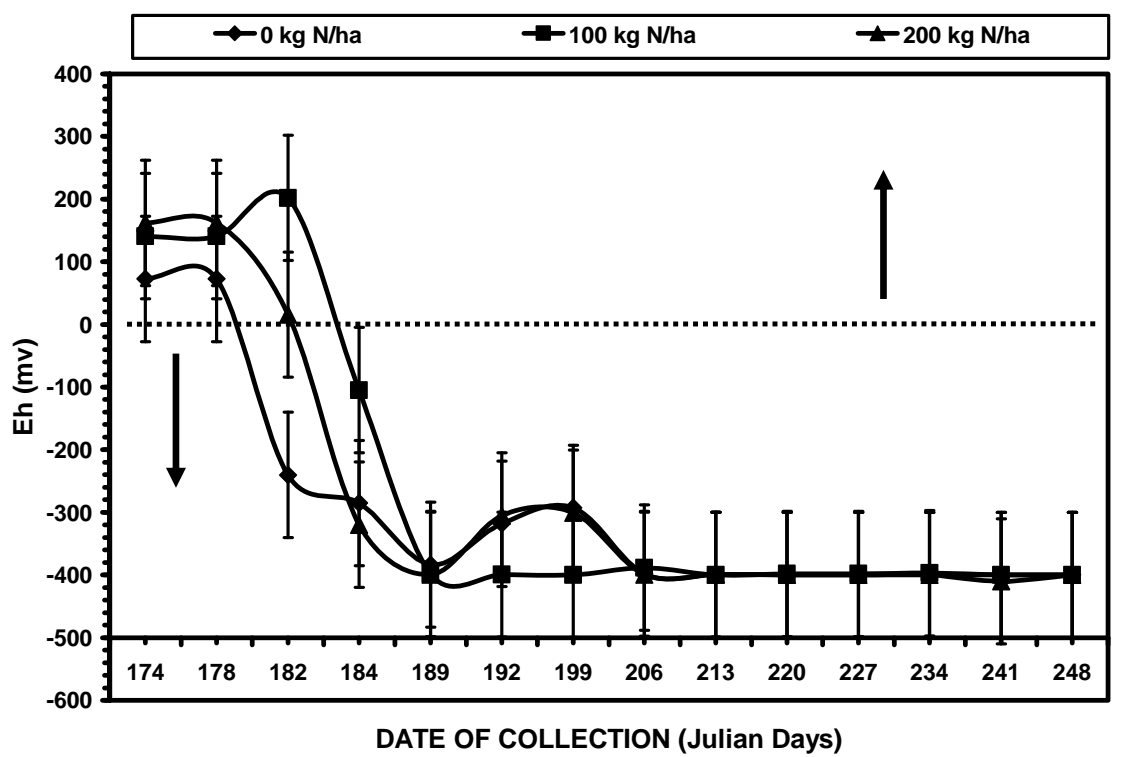

Figure 1. Average levels of reduction-oxidation (Eh) readings during the flooding experiment. 
DRY MATTER YIELD (ton $\cdot \mathrm{ha}^{-1}$ )

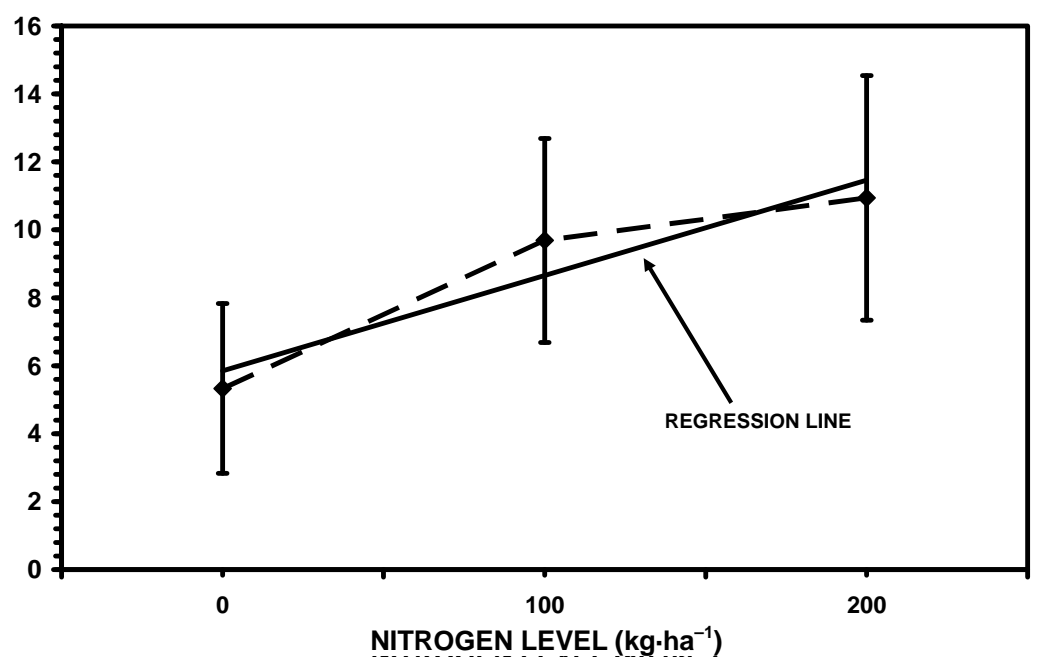

CRUDE PROTEIN CONTENT (\%)

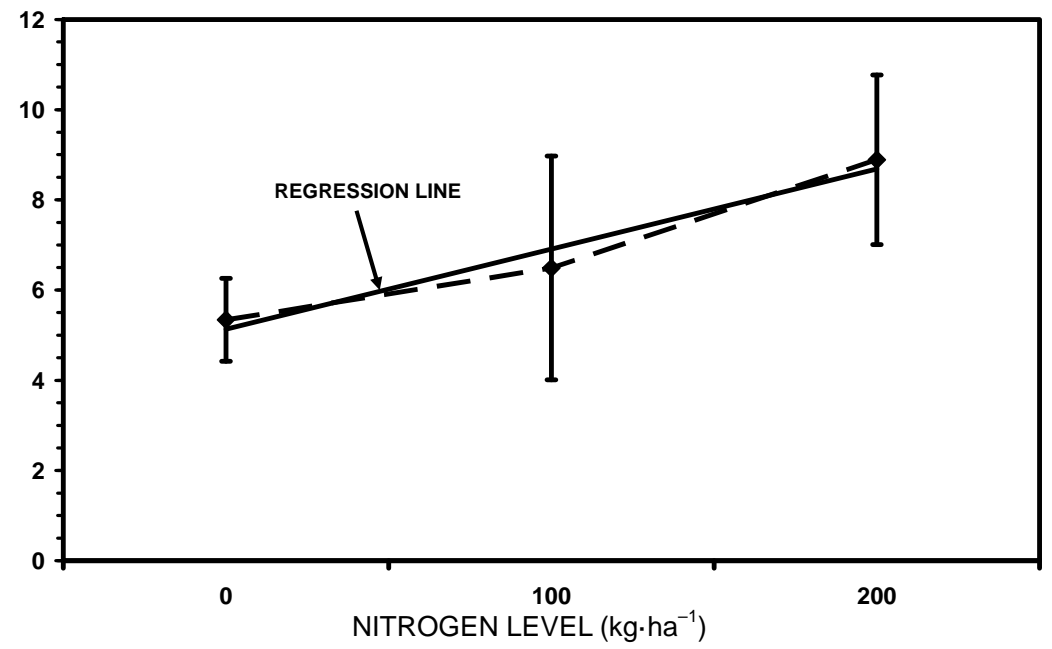

(a)

TOTAL NITROGEN CONCENTRATION IN TISSUES (\%)

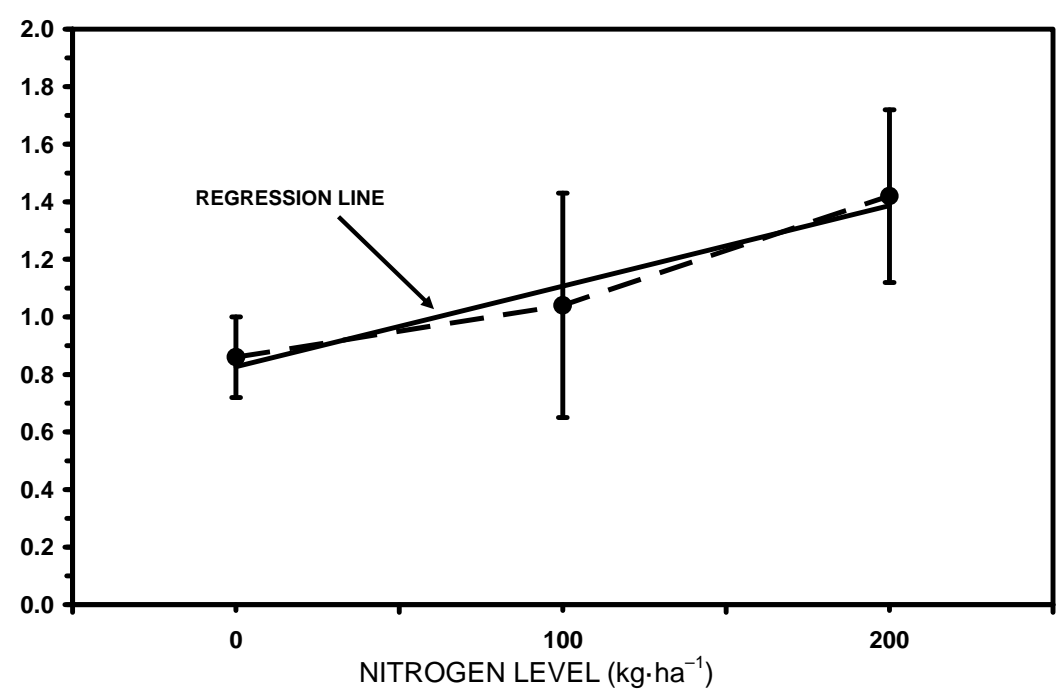


NITROGEN UPTAKE $\left(\mathrm{kg} \cdot \mathrm{ha}^{-1}\right)$

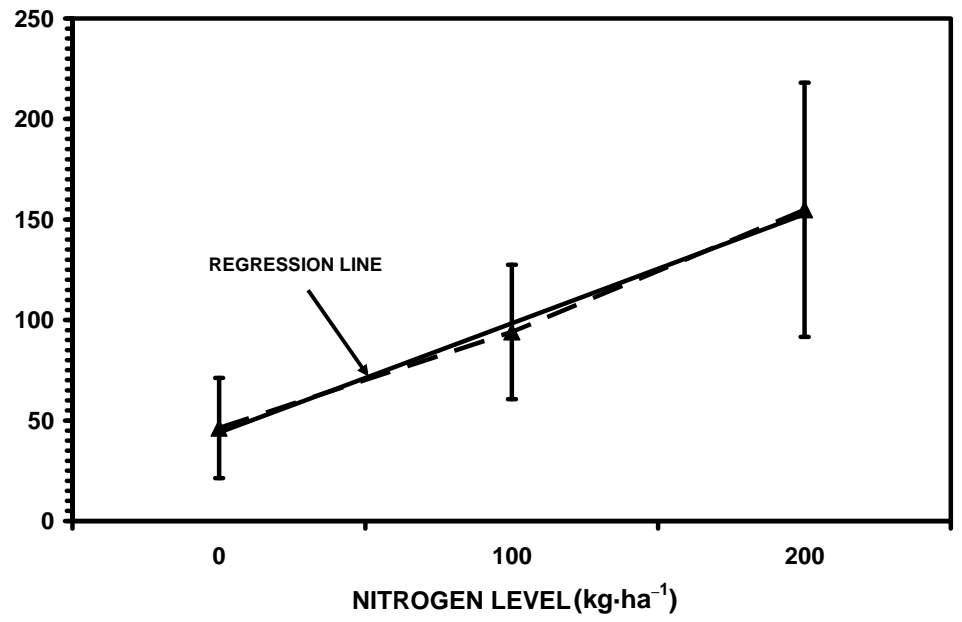

(b)

Figure 2. (a) Dry matter yield $\left(2.81 \mathrm{x}+3.04 ; R^{2}=0.91^{* *}\right)$ and crude protein content $\left(1.78 \mathrm{x}+3.36 ; R^{2}=0.96^{* *}\right)$ as affected by different levels of nitrogen fertilization; (b) Total nitrogen concentration $\left(0.28 \mathrm{x}+0.55 ; R^{2}=0.96^{* *}\right)$ and nitrogen uptake $(54.31 \mathrm{x}$ $\left.+10.26 ; R^{2}=0.99^{* *}\right)$ as affected by different levels of nitrogen fertilization.

DRY MATTER YIELD (ton'ha ${ }^{-1}$ )

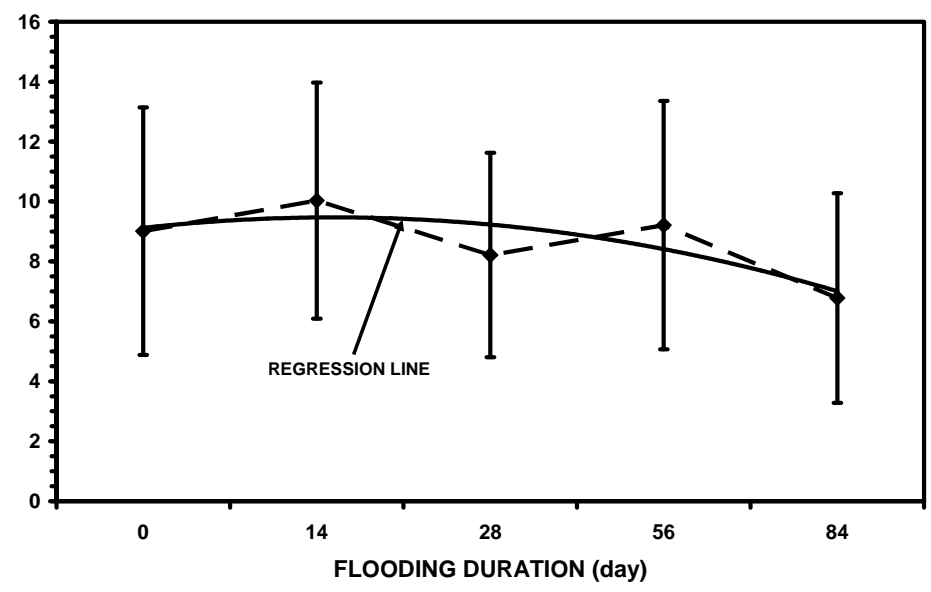

CRUDE PROTEIN CONTENT (\%)

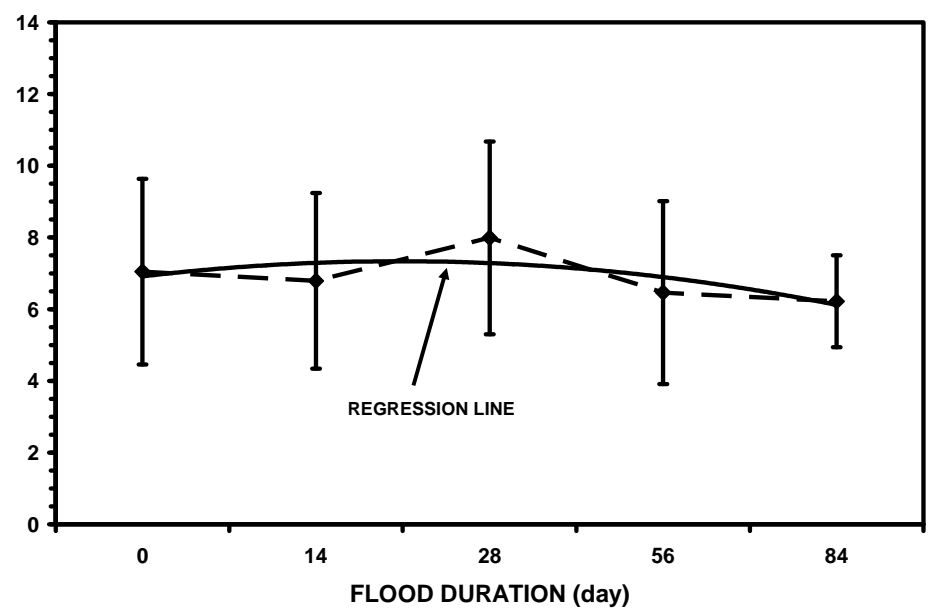

(a) 
TOTAL NITROGEN CONCENTRATION (\%)

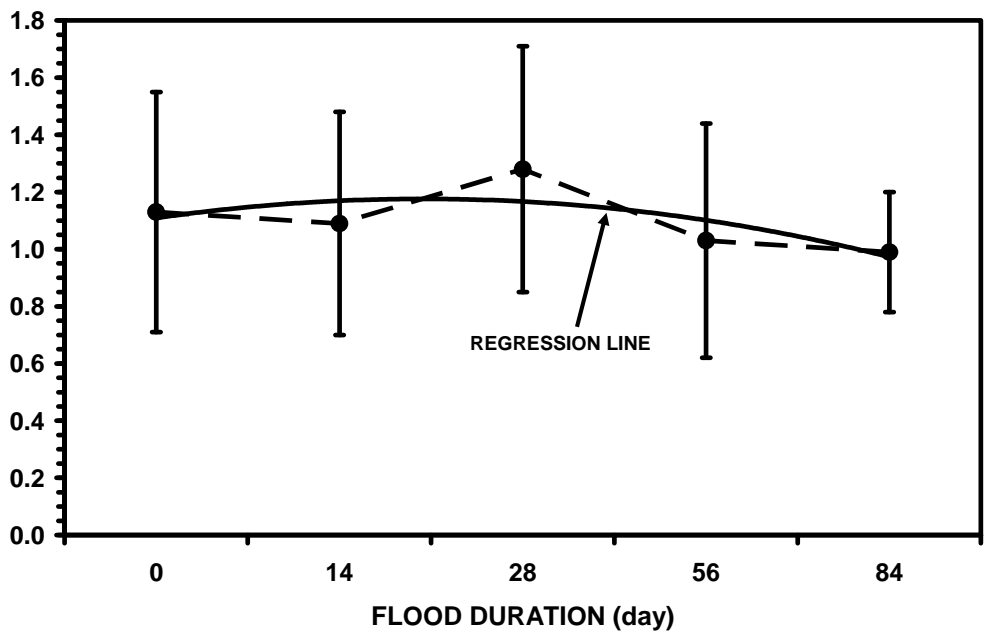

NITROGEN UPTAKE $\left(\mathrm{kg} \cdot \mathrm{ha}^{-1}\right)$

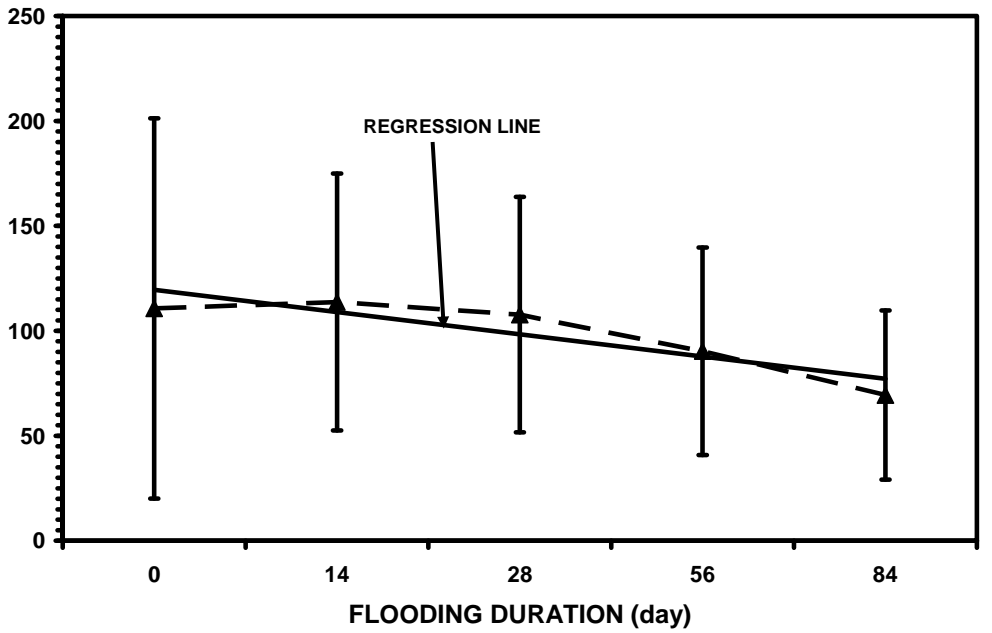

(b)

Figure 3. (a) Dry matter yield $\left(-0.29 \mathrm{x}^{2}+1.22 \mathrm{x}+8.19 ; R^{2}=0.66^{* *}\right)$ and crude protein content $\left(-0.19 \mathrm{x}^{2}+0.95 \mathrm{x}+6.15 ; R^{2}=0.49^{*}\right)$ as affected by different flooding duration; (b) Total nitrogen concentration $\left(-0.03 \mathrm{x}^{2}+0.15 \mathrm{x}+0.98 ; R^{2}\right.$ $\left.=0.50^{*}\right)$ and nitrogen uptake $\left(-10.61 \mathrm{x}+130.17 ; R^{2}=0.82^{* *}\right)$ as affected by different flooding duration.

the submerged tissues of native grasses [21,22].

\subsection{Effects on Crude Protein Content}

The CPC of bahiagrass varied widely $(p \leq 0.001)$ with the interaction effects of flooding duration and $\mathrm{N}$ fertilization. Crude protein contents of bahiagrass were also significantly affected by $\mathrm{N}$ fertilization ( $\mathrm{p} \leq 0.0001)$. Interaction of flooding duration and levels of $\mathrm{N}$ on $\mathrm{CPC}$ are shown in Table 2. The greatest amount of CPC in bahiagrass $(10.1 \%)$ was from the control tube ( 0 day flooding) with $200 \mathrm{~kg} \cdot \mathrm{N} \cdot \mathrm{ha}^{-1}$ while the least amount of CPC of $4.5 \%$ was from plants flooded with 84 days with $0 \mathrm{~kg} \cdot \mathrm{N} \cdot \mathrm{ha}^{-1}$. It appears that bahiagrass that were fertilized with higher amount of $\mathrm{N}$ have significantly higher amount of CPC when compared with those plants with no or less amount of applied $\mathrm{N}$ under any flooding duration (Table 2). These results may support the hypothesis of the study on the offsetting effect of $\mathrm{N}$ on the detrimental effect of flooding on CPC. The use of $\mathrm{N}$ fertilizer prior to flooding may alleviate $\mathrm{N}$ deficiency because waterlogging causes a significant decrease in $\mathrm{N}$ content and rate of $\mathrm{N}$ accumulation in plants due to reduced root activity. Net assimilation rates and photosynthetic rates decline in plants experiencing root anaerobiosis, in part due to stomatal closure, and in part due to biochemical modifications [1, $23]$. 
The effect of $\mathrm{N}$ fertilization on CPC is shown in Figure 2(a). The amount of CPC in bahiagrass increased linearly with increasing amount of $\mathrm{N}$ fertilization. Nitrogen fertilization for bahiagrass can be considered an adaptation to improve its nutrient uptake efficiency, and possibly may have had stimulated crude protein formation $[13,14]$. Nitrogen fertilization of pasture forages generally increases digestibility. Early reports [24-27] claimed that on bermudagrass pastures, CPC of the forage increased with each increment in $\mathrm{N}$ fertilization up to $504 \mathrm{~kg} \cdot \mathrm{ha}^{-1}$. A regression model that described the relationship of CPC with levels of $\mathrm{N}(\mathbf{x})$ is given below:

$$
\begin{aligned}
& \mathrm{CPC}_{\text {Bahiagrass }}=1.8 \mathrm{x}+3.3 \\
& R^{2}=0.97^{* *}
\end{aligned}
$$

As observed, CPC of bahiagrass was positively affected by $\mathrm{N}$ fertilization despite of anoxic environment and these results could be somehow explained by sufficient nutrients that compensate for the negative effect of waterlogging. Earlier findings of Chapin [28] and Struik and Bray [29] showed that in nutrient-rich environments, root system can satisfy plant nutrient requirements resulting in normal metabolic activities of plants including crude protein formation. The beneficial effects of $\mathrm{N}$ fertilization on CPC of bahiagrass suggest the positive impact of $\mathrm{N}$ on keeping a good quality of forage even under waterlogged condition. Early published report of Sigua and Hudnall [30] confirmed the importance of gypsum and $\mathrm{N}$ fertilization on protein contents of four specie of wetland vegetation under saline environment. Their results disclosed highly significant protein content responses to gypsum and $\mathrm{N}$ additions. Increased growth, yield, and protein content were observed from plants that were fertilized with nitrogen.

\subsection{Effects on Nitrogen Uptake}

Total nitrogen uptake (NUP) of bahiagrass varied significantly ( $\mathrm{p} \leq 0.0001)$ with $\mathrm{N}$ fertilization, but was neither affected by flooding duration nor by the interaction of flooding duration and $\mathrm{N}$ fertilization (Table 2). It appears that bahiagrass that were fertilized with higher amount of $\mathrm{N}$ have significantly higher amount of NUP when compared with those plants with no or less amount of applied $\mathrm{N}$ under any flooding duration (Table 2). The greatest amount of NUP was from plants $\left(187 \mathrm{~kg} \cdot \mathrm{N} \cdot \mathrm{ha}^{-1}\right)$ that were fertilized with $200 \mathrm{~kg} \cdot \mathrm{N} \cdot \mathrm{ha}^{-1}$ with 0 day of flooding. Bahiagrass that were flooded for 84 days and did not receive $\mathrm{N}$ fertilization had the lowest NUP of 23 $\mathrm{kg} \cdot \mathrm{N} \cdot \mathrm{ha}^{-1}$. These results demonstrated the mitigating effect of $\mathrm{N}$ fertilization in offsetting the negative impact of flooding could be mitigated by $\mathrm{N}$ fertilization.

The effect of $\mathrm{N}$ fertilization on NUP is shown in Figure 2(b). The amount of NUP increased linearly with increasing amount of $\mathrm{N}$ fertilization when averaged across flooding duration. The relationship between NUP and levels of $\mathrm{N}$ fertilization ( $\mathrm{x}$ ) was described by a regression model given below:

$$
\begin{aligned}
& \mathrm{NUP}_{\text {Bahiagrass }}=54.31 \mathrm{x}+10.26 \\
& R^{2}=0.99^{* *}
\end{aligned}
$$

Results disclosed an overwhelming effect of $\mathrm{N}$ application on NUP. Averaged across flooding duration, bahiagrass that were fertilized at $200 \mathrm{~kg} \cdot \mathrm{N} \cdot \mathrm{ha}^{-1}$ had an increase of about $235 \%$ NUP when compared with the control plants $\left(0 \mathrm{~kg} \cdot \mathrm{N} \cdot \mathrm{ha}^{-1}\right)$. Bahiagrass that were fertilized with $100 \mathrm{~kg} \cdot \mathrm{N} \cdot \mathrm{ha}^{-1}$ had an increase in NUP of about $103 \%$ when compared with the control plant. The increase in the amount of NUP between plants that were fertilized with 100 and $200 \mathrm{~kg} \cdot \mathrm{N} \cdot \mathrm{ha}^{-1}$ was doubled $(103 \%$ to 235\%) significantly (Table 2 and Figure 2(b)).

As shown in Figure 3(b), the NUP of bahiagrass was relatively comparable across flooding duration. The average NUP of bahiagrass was negatively affected by increasing duration of flooding (x). This relationship was described by a regression model given below:

$$
\begin{aligned}
& \mathrm{NUP}_{\text {Bahiagrass }}=-10.61 \mathrm{x}+130.17 \\
& R^{2}=0.82^{* *}
\end{aligned}
$$

Nitrogen uptake of bahiagrass being classified as a facultative (FACU+) upland species may have been reduced under periods of extended waterlogging. The lowest amount of NUP in bahiagrass was observed from plants that were flooded for 84 days. The greatest amount of NUP was observed from plants that were flooded between 0 and 14 days (Table 2). The lower NUP of bahiagrass could be related to anaerobic conditions that inhibit almost immediately the transport of nutrient ions by roots [3]. This may be due to insufficient energy to maintain the activity of ion pumps. Phloem unloading in the anaerobic root ceases and transport of metabolites and growth regulators between the root and shoot are therefore impeded.

\section{SUMMARY AND CONCLUSIONS}

A study was conducted to determine the potential ecological impact of flooding duration and $\mathrm{N}$ fertilization on yield, protein content and $\mathrm{N}$ uptake of bahiagrass under greenhouse conditions in 2008 and 2009. The overall results and observations in this study could be briefly summarized as follows:

1) Results disclosed that yield, crude protein content, and nitrogen uptake of bahiagrass varied significantly with levels of $\mathrm{N}$ fertilization;

2) Yield and nitrogen uptake of bahiagrass were not as significantly affected by flooding duration as $\mathrm{N}$ application. Bahiagrass can survive an extended periods of flood- 
ing between 14 and 28 days;

3) Average NUP of bahiagrass was negatively affected by increasing duration of flooding which can be described by this relationship: $-10.6 \mathrm{x}+130.2 ; R^{2}=0.82^{* *}$;

4) The yield response, crude protein content, and nitrogen uptake of bahiagrass was linearly related to increasing levels of $\mathrm{N}$ application;

5) Negative impact of flooding on yield and nitrogen uptake of bahiagrass may have been mitigated by $\mathrm{N}$ fertilization.

\section{REFERENCES}

[1] Trought, M.C. and Drew, M.C. (1980) The development of waterlogging in wheat seedlings. I. Shoot and root growth in relation to changes in the concentration of dissolved gases and solutes in the soil solution. Plant Soil, 54, 77-94. doi:10.1007/BF02182001

[2] Jackson, M.B. (1985) Ethylene and the responses of plants to soil waterlogging and submergence. Annual Review of Plant Physiology, 36, 145-174. doi:10.1146/annurev.pp.36.060185.001045

[3] Luttge, V. and Pittman, M.G. (1976) Transport and Energy. Encyclopedia Plant Physiol, 2, 251-259.

[4] Chambliss, C.G. (1999) Bahiagrass. In: Chambliss, C.G., Ed., Florida Forage Handbook, University of Florida, Gainesville, 90.

[5] Naidoo, G. and Mundree, S.G. (1993) Relationship between morphological and physiological responses to waterlogging and salinity in Sporobolus virginicus (L.). Oecologia, 93, 360-366. doi:10.1007/BF00317879

[6] Rubio, G., Casasola, G. and Lavado, R.S. (1995) Adaptation and biomass production of two grasses in response to waterlogging and soil nutrient enrichment. Oecologia, 102, 102-105.

[7] Crawford, R.M. (1993) Plant survival without oxygen. Biologist, 40, 110-114.

[8] Drew, M.C., Sisworo, E.J. and Saker, L.R. (1979) Alleviation of waterlogging damage to young barley plants by application of nitrate and synthetic cytokinin. New Phytologist, 82, 315-329. doi:10.1111/j.1469-8137.1979.tb02657.x

[9] Hodgson, A.S. (1982) The effects of duration, timing and chemical amelioration of short-term waterlogging during furrow irrigation of cotton in cracking gray soil. Australian Journal of Agricultural Research, 33, 1019-1028. doi:10.1071/AR9821019

[10] Gallagher, R.N., Weldon, G.O. and Boswell, F.C. (1976) A semi-automated procedure for total nitrogen in plant and soil samples. Soil Science Society of America Journal, 40, 887-889. doi:10.2136/sssaj1976.03615995004000060026x

[11] SAS Institute (2000) SAS/STAT user's guide. Release 6.03. SAS Institute, Cary.

[12] Voesenek, L.A.C.J., Colmer, T.D., Pierik, R., Millenaar, F.F., Peeters, A.J. and Peeters, M. (2006) How plants cope with complete submergence. New Phytologist, 170, 213-

\section{6. doi:10.1111/j.1469-8137.2006.01692.x}

[13] Atkinson, D. (1973) Some general effects of phosphorus deficiency on growth and development. New Phytologist, 72, 101-111. doi:10.1111/j.1469-8137.1973.tb02014.x

[14] Aerts, R. and Vander, P.J.M. (1991) The relation between above- and belowground biomass allocation patterns and competitive ability. Oecologia, 87, 551-559. doi:10.1007/BF00320419

[15] Kozlowski, T.T. (1984) Plant responses to flooding. BioScience, 34, 162-167. doi:10.2307/1309751

[16] Heathcote, C.A., Davies, M.S. and Etherington, J.R. (1987) Phenotypic flexibility of Carex flacca (Shreb) tolerance of soil flooding by populations from contrasting habitats. New Phytologist, 105, 381-392. doi:10.1111/j.1469-8137.1987.tb00875.x

[17] Naidoo, G. and Naidoo, S. (1992) Waterlogging responses of Sporobolus virginicus (L.) Kunth. Oecologia, 90, 445450. doi:10.1007/BF00317704

[18] Loreti, J. and Oesterheld, M. (1996) Intraspecific variation in the resistance to flooding and drought in populations of Paspalum dilitatum from different topographic positions. Oecologia, 92, 279-284.

[19] Crawford, R.M., Studer, C. and Studer, K. (1989) Deprivation indifference as a survival strategy in competition, advantages and disadvantages of anoxia tolerance in wetland vegetation. Flora, 182, 189-201.

[20] Insausti, P., Chaneton, E.J. and Soriano, A. (1999) Flooding reverted grazing effects on plant community structure in mesocosms of lowland grassland. Oikos, 84, 266-276. doi: $10.2307 / 3546721$

[21] Laan, P., Tosserama, M., Blom, C.W.P.M. and Veen, B.W. (1990) Internal oxygen transport in Rumex species and its significance for respiration under hypoxic conditions. Plant and Soil, 122, 39-46. doi:10.1007/BF02851908

[22] Van der Samn, A.J.M., Voesenek, L.A.C.J., Blom, C.W.P.M., Harren, F.J.M. and Reuss, J. (1991) The role of ethylene in shoot elongation with respect to survival and seed output of flooded Rumes maritimus L. plants. Functional Ecology, 5, 304-313. doi:10.2307/2389269

[23] Jackson, M.B., Drew, M.C. (1984) Effects of flooding on growth and metabolism of herbaceous plants. In: Kozlowski, E.T., Ed., Flooding and Plant Growth, Academic Press, Orlando, 47-128.

[24] Hart, R.H., Burton, G.W. and Jackson, J.E. (1965) Seasonal variation in chemical composition and yield of coastal bermudagrass as affected by nitrogen fertilization schedule. Agronomy Journal, 57, 381-385. doi:10.2134/agronj1965.00021962005700040022x

[25] Mathias, E.L., Bennet, O.L. and Lundberg, P.E. (1973) Effect of rates of nitrogen on yield, nitrogen use, and winter survival of Midland bermudagrass (Cynodon dactylon, L.) in Appalachia. Agronomy Journal, 65, 65-67.

[26] Horn, F.P. and Taliaferro, C.M. (1974) Yield, composition, and IVDMD of four bermudagrass. Journal of Animal Science, 38, 224.

[27] Barth, K.M., McLaren, J.B., Fribourg, H.A. and Carver, L.A. (1982) Crude protein content of forage consumed by steers grazing $\mathrm{N}$-fertilized. Bermuda grass and Orchard 
Grass-Ladino clover pastures. Journal of Animal Science, 55, 1008- 1014.

[28] Chapin, F.S. (1980) The mineral nutrition of wild plants. Annual Reviews of Ecology and Systematics, 11, 233-260. doi:10.1146/annurev.es.11.110180.001313

[29] Struik, G. and Bary, J.R. (1970) Root-shoot ratios of native forest herbs and Zea mays at different soil-moisture levels.
Ecology, 51, 892-893. doi:10.2307/1933983

[30] Sigua, G.C. and Hudnall, W.H. (1992) Nitrogen and gypsum, management tools for revegetation and productivity improvement of brackish marsh in southwest Louisiana. Communications in Soil Science and Plant Analysis, 23, 283-299. doi:10.1080/00103629209368588 